\title{
Patterns of Species, Phylogenetic and Mimicry Diversity of Clearwing Butterflies in the Neotropics
}

\author{
Nicolas Chazot, Keith R. Willmott, André V.L. Freitas, Donna Lisa de Silva, \\ Roseli Pellens, and Marianne Elias
}

\begin{abstract}
The Neotropical region comprises six of the major biodiversity hotspots of the planet, including the Andean foothills, which harbour the most diverse terrestrial ecosystems. It is also one of those most threatened by habitat destruction and climatic changes, which cause species extirpation and sometimes extinction, resulting in community disassembly and loss of interspecific interactions. The effects of community disassembly can be particularly strong in highly coevolved mutualistic species assemblages, such as Müllerian mimetic species. Conservation strategies should therefore aim at preserving not only evolutionary diversity, but also species interactions. Here we use mimetic ithomiine butterflies (Nymphalidae: Danainae, Ithomiini) as a model to identify areas of both evolutionary and ecological importance, and hence conservation significance. Ithomiine butterflies form a tribe of ca. 380 species that inhabit lowland and montane Neotropical forests. All species engage in Müllerian mimicry, and drive mimicry in other, distantly related, Lepidoptera. We analyse phylogenetic, distribution and mimicry data for three diverse ithomiine genera, Napeogenes, Ithomia and Oleria. We use different metrics to study geographical patterns of diversity. Patterns of species richness, phylogenetic diversity and mimicry diversity are highly congruent within genera but slightly different among genera. Mountainous regions contain the greatest taxonomic and mimetic diversity in ithomiines, with the Andean foothill region being
\end{abstract}

\footnotetext{
N. Chazot $(\bowtie) \bullet$ D.L. de Silva $\bullet$ R. Pellens $\bullet$ M. Elias Institut de Systématique, Evolution, Biodiversité, ISYEB - UMR 7205 CNRS MNHN UPMC EPHE, Muséum National d'Histoire Naturelle, Sorbonne Universités, 45 rue Buffon, CP 50, 75005 Paris, France

e-mail: chazotn@gmail.com; lisadesilva@yahoo.co.uk; pellens@mnhn.fr; elias@mnhn.fr

K.R. Willmott

McGuire Center for Lepidoptera and Biodiversity, Florida Museum of Natural History,

University of Florida, Gainesville, FL 32611, USA

e-mail: kwillmott@flmnh.ufl.edu
}

\section{A.V.L. Freitas}

Departamento de Zoologia and Museu de História Natural, Instituto de Biologia, Universidade Estadual de Campinas, Campinas, São Paulo, Brazil

e-mail: baku@unicamp.br 
the area of highest diversity, but other regions, such as Central America and the upper Amazon, are also important. Finally, a measure of vulnerability related to mimicry indicates that mutualistic interactions are not distributed evenly across space and genera. We argue that mutualistic interactions should be taken into account in conservation strategies.

Keywords Ithomiini • Müllerian mimicry • Phylogenetic diversity • Amazonia • Andes

\section{Introduction}

The Neotropical region extends from Mexico to northern Argentina, including the Amazon basin, the Andean cordillera and the Atlantic Forest. It is the most biologically diverse of the world's major biogeographic regions (Gaston and Hudson 1994; Myers et al. 2000; Hawkins et al. 2007). At least one million species of insects, 40,000 of plants, 3000 of fishes, 1294 of birds, 427 of mammals, 427 of amphibians, and 378 of reptiles inhabit the Amazonian basin (Da Silva et al. 2005a). It is also a region of high endemism, including 6 of the world's 25 biodiversity 'hotspots' (Myers et al. 2000).

Many areas of the Neotropics are under continual threat from deforestation. In 2004, ca. 2.7 million ha of forest were cleared in Amazonia alone (INPE). In Central America, only $1.7 \%$ of the original dry forest remains, and most of this comprises small, isolated patches (Griscom and Ashton 2011). Similarly, the Atlantic forest has been reduced to $12 \%$ of its original area, with astonishing rates of deforestation every year (SOS Mata Atlântica, INPE, ISA 1998; Ribeiro et al. 2009). In Amazonia, wood extraction, industrial logging, cattle pastures, banana plantations and more recently oil palm culture are the main causes of the ongoing deforestation. The Neotropics are also threatened by climatic changes, which are likely to be particularly serious in mountain habitats (e.g., Engler et al. 2009; Chen et al. 2011; Feeley et al. 2011). Habitat destruction and climatic changes may cause species extirpation, displacements and extinction (e.g., Loiselle et al. 2010), which may in turn result in community disassembly, with loss of interspecific interactions (Sheldon et al. 2011). The consequences of community disassembly can be particularly strong in highly coevolved mutualistic species assemblages, such as insect-pollinator networks, plant species engaged in facilitation, or Müllerian mimetic species (Chazot et al. 2014).

To preserve Neotropical biodiversity, given constraints of time and money, it is essential to identify priority areas for conservation (Williams et al. 1996). However, there are several problems in identifying such areas. Firstly, distribution data are not available for all taxa, so attention has focused on indicator taxa, which are expected to reliably indicate patterns of diversity in other, more poorly known groups (e.g., Howard et al. 1998; Lamoreux et al. 2006). Insects constitute at least $70 \%$ of all terrestrial organisms (Samways 1994), and their outstanding evolutionary success 
in virtually all terrestrial habitats potentially makes them one of the most valuable study groups for understanding the distribution and origins of biodiversity, and for developing efficient means to conserve that biodiversity (Brown 1997). However, because of the diversity of insects and taxonomic difficulties in many groups, some authors have suggested that conservation research be focused on a few suitable taxa, such as butterflies (New 1993; Brown and Freitas 2000; Bonebrake et al. 2010; Basset et al. 2013). Butterflies can be used to monitor ecosystem health (e.g. Warren et al. 2001), reveal broadly applicable patterns of diversity and endemism, and effectively communicate complex scientific ideas to the public and generate popular support for conservation (Sparrow et al. 1994; Boggs et al. 2003).

One of the best studied diverse groups of Neotropical butterflies is the tribe Ithomiini (Nymphalidae: Danainae), an exclusively Neotropical group which currently includes about 380 species placed in 47 genera (Lamas 2004; Willmott and Lamas 2007). Ithomiines occur from Mexico to Argentina and are largely restricted to moist forest habitats from sea level up to $3000 \mathrm{~m}$ (Beccaloni 1997a). Among the attributes that make the group a potentially useful indicator of conservation priorities for other taxa are its diversity, its broad range of occupied elevations, its abundance in the field and collections, the broad variation in range size among species, and its good level of taxonomic knowledge.

Having selected a potentially suitable indicator taxon, the next issue is to decide what surrogate measure of biodiversity will be used (Williams et al. 1996). Species richness is the most commonly used measure, but it may not represent important aspects of the structure and composition of natural communities. A species richness measure considers all species as equal, ignoring their functional or phylogenetic relationships (e.g., Safi et al. 2011). As an alternative, measures of phylogenetic diversity evaluate species in terms of the amount of unique evolutionary history they represent. The loss of species with no close relatives represents the extinction of an entire lineage, resulting in a greater loss to biodiversity than the loss of a species that shares most of its evolutionary history with another (Mace et al. 2003; Mooers et al. 2005; Maclaurin and Sterelny 2008). During the last two decades several metrics have been developed to assess the phylogenetic diversity of clades and to evaluate and compare communities for conservation based on the phylogenetic diversity of the species they harbour (e.g., Vane-Wright et al. 1991; Faith 1992). Despite the difficulty of defining the most adequate metric (see Redding et al. 2008; Schweiger et al. 2008), and the circumstances where phylogenetics can be useful for conservation (e.g., Rodrigues et al. 2005; Hartmann and Andre 2013), two points emerged from these studies. The first is that conservation strategies based on phylogenetic measures capture more evolutionary diversity than strategies ignoring phylogeny (e.g., Hartmann and Steel 2007; Redding et al. 2008), and the second is that extinctions are not random in the tree of life, but rather are phylogenetically and functionally clumped (Purvis et al. 2000; Yessoufou et al. 2012). In the last few years several phylogenies have become available for the Ithomiini as a whole (Brower et al. 2014; Willmott and Freitas 2006), and also for some speciose clades inside this tribe (Mallarino et al. 2005; Elias et al. 2009; de-Silva et al. 2015). This phylogenetic information thus allows us to consider phylogenetic diversity in an assessment of conservation priorities for Neotropical insects. 
In addition to evolutionary diversity, ecological interactions represent another important component of biodiversity that is rarely addressed in conservation prioritization. While difficult to characterize for many insects, ecological interactions among ithomiines have received an unusual amount of attention since these butterflies illustrate some of the most outstanding examples of mutualistic, Müllerian mimicry (Müller 1879). Ithomiines are considered, together with the Heliconiini, the central models in many Neotropical Lepidoptera mimicry rings (Brown and Benson 1974; Beccaloni 1997a). Chemical compounds acquired by adult feeding (Brown 1984, 1985) make ithomiines unpalatable to their predators, which learn to avoid the aposematic wing patterns exhibited by ithomiines. The wing colour patterns of co-existing species are under strong selection for convergence, thereby reducing the individual cost of educating predators (Müller 1879; Mallet 1999), and the resulting 'mimicry rings' contain multiple co-mimetic species which interact mutualistically (Fig. 1). Co-mimetic ithomiines tend to share habitats (Chazot et al. 2014). They also tend to share hostplants (Willmott and Mallet 2004), fly at similar heights above the ground (Beccaloni 1997b; Elias et al. 2008) and fly in similar forest microhabitats (DeVries et al. 1999; Elias et al. 2008; Hill 2010). These tightly-knit webs of interactions may thus be particularly sensitive to community disassembly caused by habitat or climate change (Sheldon et al. 2011), with the potential for cascading co-extinctions due to the loss of a few species whose presence facilitates the existence of other species. Because mutualistic interactions are particularly easy to characterize in ithomiines (species that share the same wing pattern interact mutualistically, species with different wing patterns do not), this group provides a unique opportunity to assess the importance of mutualistic interactions from a conservation perspective.

Studies combining phylogenetic and ecological or functional data to characterize biodiversity patterns and their association with environmental gradients (Devictor et al. 2010; Flynn et al. 2011; Duarte et al. 2012), as well as to test conservationfocused hypotheses (Faith 2008; Safi et al. 2011), are likely to better represent biodiversity and hopefully to guide conservation in a more precise way. Here, we use distribution, phylogenetic and mimicry data for three diverse ithomiine genera, Ithomia, Napeogenes and Oleria, to identify areas of maximal species, phylogenetic and mimicry diversity for each of these genera. We also identify areas of maximum and minimum vulnerability in terms of proportion of potential loss of species due to disruption of mimicry rings. With these three independent replicates we then explore whether different metrics show peaks in the same areas, and whether the different taxa show similar spatial patterns of diversity.

\section{Material and Methods}

\section{The Neotropics}

In this study we refer to the following specific areas within the Neotropical region (Fig. 2): (1) Central America, which extends from Panama to Mexico; (2) the western/northern Andes and (3) the eastern Andes, which usually exhibit distinct faunas; 
EURIMEDIA

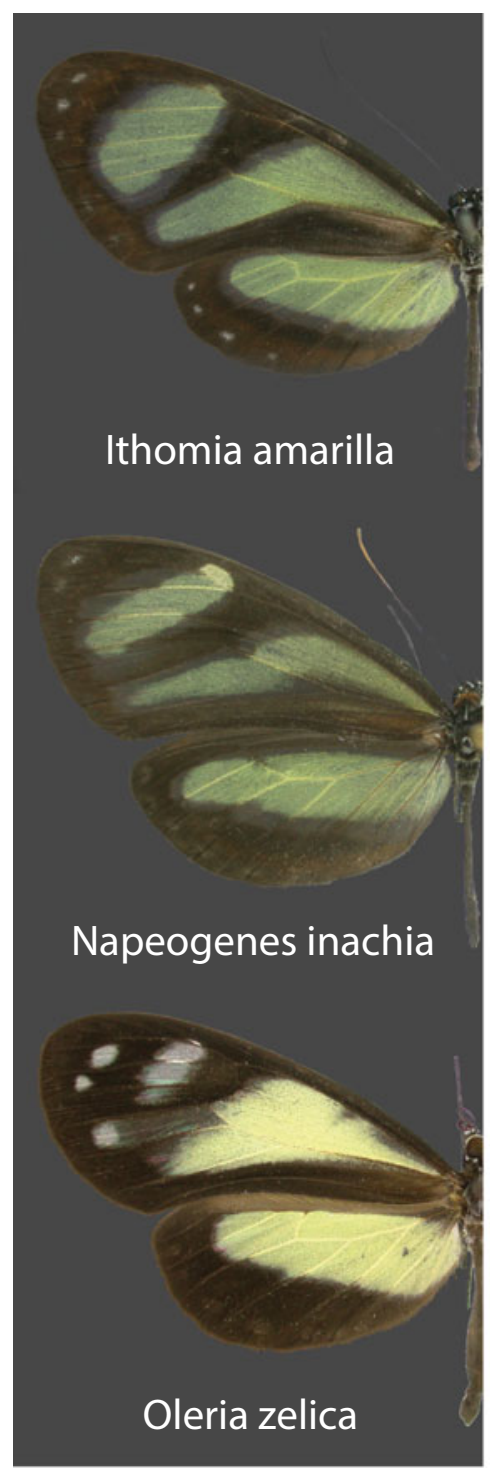

\section{BANJANA-M}

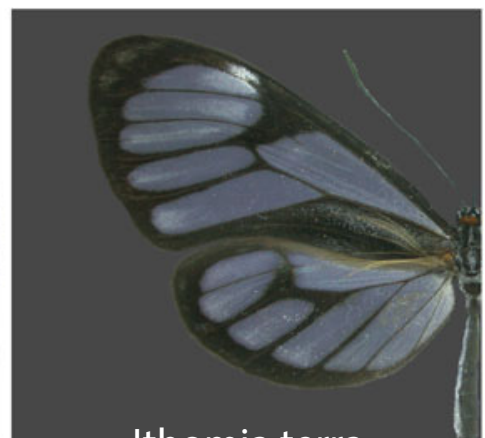

Ithomia terra

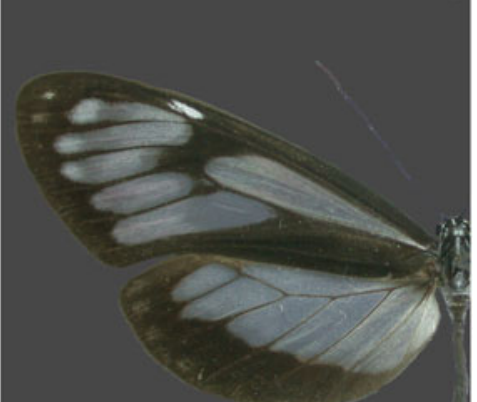

Napeogenes harbona

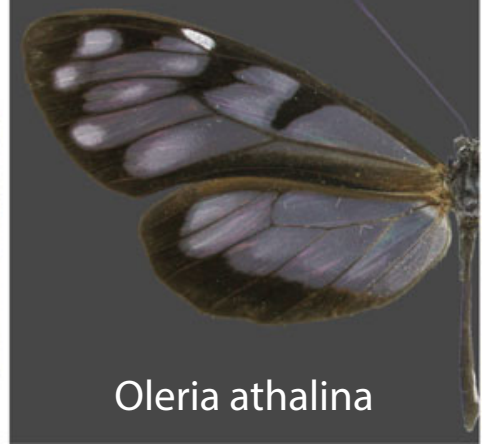

Fig. 1 Two examples of mimicry rings named eurimedia and banjana-m, each one shared by a species of the three genera under interest 


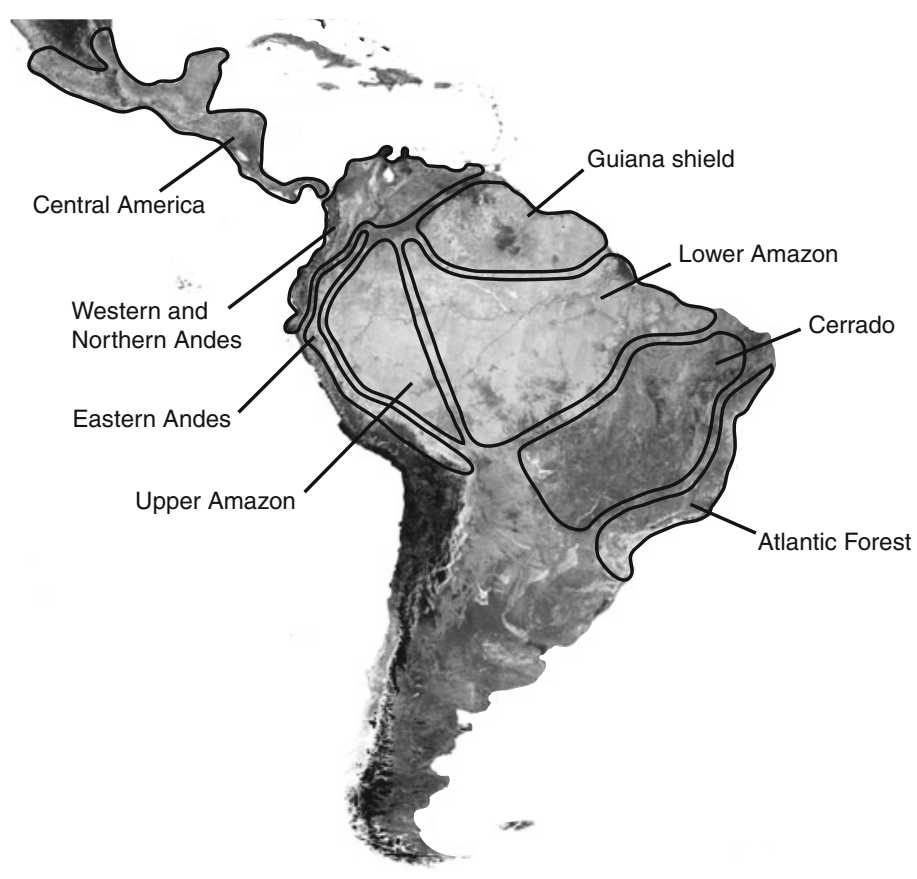

Fig. 2 Neotropical regions used in this study

(4) the upper Amazon along the eastern foothills of the Andes; (5) the lower Amazon; (6) the Guiana shield; (7) the Cerrado, which separates the Amazon basin and the Atlantic Forest and (8) the Atlantic Forest, which extends along the south-east and southern Brazilian coast and adjacent inland regions.

\section{Study Groups and Phylogenies}

In this chapter we focus on three ithomiine genera (Table 1) for which nearly comprehensive calibrated molecular phylogenies are available in the literature: Ithomia (24 out of 25 extant species, Mallarino et al. 2005; Jiggins et al. 2006; Elias et al. 2009); Napeogenes (24 out of 24 extant species, Elias et al. 2009) and Oleria (42 out of 49 extant species, de-Silva et al. 2015; de-Silva et al. 2010). We analyse the three genera independently to assess the congruence of geographical diversity patterns among genera. All the trees used are ultrametric, with branch lengths proportional to time. 


\section{Mimicry Classification}

Species were classified among 23 mimicry groups, following previous classification (e.g., Willmott and Mallet 2004; Jiggins et al. 2006; Elias et al. 2008, Table 1 and Fig. 1).

Table 1 List of the species of Ithomia, Napeogenes and Oleria, with their mimicry patterns. (Species may harbour multiple geographical races with different mimicry patterns)

\begin{tabular}{l|l|l}
\hline Genus & Species & Mimicry pattern \\
\hline Ithomia & adelinda & confusa, mestra, praxilla \\
\hline Ithomia & agnosia & agnosia, lerida \\
\hline Ithomia & amarilla & eurimedia \\
\hline Ithomia & arduinna & agnosia, eurimedia \\
\hline Ithomia & avella & ticida-m, banjana-m, panthyale \\
\hline Ithomia & celemia & hermias, mamercus, parallelis \\
\hline Ithomia & cleora & mantineus \\
\hline Ithomia & diasia & amalda, lerida \\
\hline Ithomia & drymo & lerida \\
\hline Ithomia & eleonora & banjana-m \\
\hline Ithomia & ellara & banjana-m \\
\hline Ithomia & heraldica & mamercus \\
\hline Ithomia & hyala & lerida \\
\hline Ithomia & hymettia & agnosia, banjana-m \\
\hline Ithomia & iphianassa & dilucida, hermias, idae \\
\hline Ithomia & jucunda & amalda, lerida \\
\hline Ithomia & lichyi & agnosia, lerida \\
\hline Ithomia & patilla & lerida \\
\hline Ithomia & praeithomia & banjana-m \\
\hline Ithomia & pseudoagalla & dilucida \\
\hline Ithomia & salapia & agnosia, derama, eurimedia \\
\hline Ithomia & terra & agnosia, banjana-m, lerida \\
\hline Ithomia & xenos & dilucida \\
\hline Napeogenes & aethra & hermias \\
\hline Napeogenes & apulia & mestra, ocna \\
\hline Napeogenes & benigna & dilucida, panthyale \\
\hline Napeogenes & cranto & dilucida, eurimedia \\
\hline Napeogenes & duessa & duessa, eurimedia, mamercus \\
\hline Napeogenes & flossina & panthyale \\
\hline Napeogenes & glycera & mestra, ocna, praxilla \\
\hline & & \\
\hline
\end{tabular}


Table 1 (continued)

\begin{tabular}{|c|c|c|}
\hline Genus & Species & Mimicry pattern \\
\hline Napeogenes & gracilis & ozia \\
\hline Napeogenes & harbona & $\begin{array}{l}\text { banjana-m, susiana, derasa, } \\
\text { mestra, unknown }\end{array}$ \\
\hline Napeogenes & inachia & eurimedia, hemixanthe \\
\hline Napeogenes & larilla & $\begin{array}{l}\text { banjana-m, hewitsoni, } \\
\text { panthyale, theudelinda }\end{array}$ \\
\hline Napeogenes & lycora & ozia, praxilla \\
\hline Napeogenes & nspl & ocna \\
\hline Napeogenes & $n s p 2$ & banjana-m, ocna \\
\hline Napeogenes & peridia & $\begin{array}{l}\text { dilucida, excelsa, hecalesina, } \\
\text { hermias }\end{array}$ \\
\hline Napeogenes & pharo & $\begin{array}{l}\text { confusa, derasa, eurimedia, } \\
\text { ozia }\end{array}$ \\
\hline Napeogenes & rhezia & $\begin{array}{l}\text { eurimedia, hemixanthe, } \\
\text { hermias, mamercus, mothone }\end{array}$ \\
\hline Napeogenes & sodalis & agnosia \\
\hline Napeogenes & stella & dilucida, hermias \\
\hline Napeogenes & sulphureophila & ocna \\
\hline Napeogenes & sylphis & $\begin{array}{l}\text { agnosia, aureliana, egra, } \\
\text { illinissa, lerida }\end{array}$ \\
\hline Napeogenes & tolosa & $\begin{array}{l}\text { dilucida, eurimedia, excelsa, } \\
\text { mamercus }\end{array}$ \\
\hline Napeogenes & verticilla & agnosia \\
\hline Napeogenes & zurippa & hermias, mamercus, orestes \\
\hline Oleria & aegle & egra, lerida \\
\hline Oleria & agarista & aureliana, lerida, sinilia \\
\hline Oleria & alexina & agnosia \\
\hline Oleria & amalda & amalda, lerida \\
\hline Oleria & antaxis & egra, lerida, sinilia \\
\hline Oleria & aquata & lerida \\
\hline Oleria & assimilis & angosia, aureliana, lerida \\
\hline Oleria & astrea & lerida \\
\hline Oleria & athalina & banjana-m, susiana \\
\hline Oleria & attalia & mestra, susiana \\
\hline Oleria & baizana & banjana-m, hewitsoni \\
\hline Oleria & bioculata & agnosia \\
\hline Oleria & boyeri & agnosia \\
\hline Oleria & cyrene & banjana-m, susiana \\
\hline Oleria & deronda & banjana-m, thabena-f \\
\hline Oleria & derondina & $\begin{array}{l}\text { banjana-m, thabena-f, } \\
\text { panthyale }\end{array}$ \\
\hline Oleria & didymaea & agnosia, lerida \\
\hline
\end{tabular}


Table 1 (continued)

\begin{tabular}{l|l|l}
\hline Genus & Species & Mimicry pattern \\
\hline Oleria & enania & agnosia, aureliana, lerida \\
\hline Oleria & estella & agnosia, quintina \\
\hline Oleria & fasciata & banjana-m, susiana \\
\hline Oleria & flora & egra, lerida \\
\hline Oleria & fumata & banjana-m \\
\hline Oleria & gunilla & agnosia, aureliana, illinissa, \\
& lerida, quintina, sinilia \\
\hline Oleria & ilerdina & aureliana, illinissa, lerida \\
\hline Oleria & makrena & agnosia, banjana-m \\
\hline Oleria & onega & agnosia, aureliana, lerida, \\
& & quintina \\
\hline Oleria & padilla & agnosia, banjana-m \\
\hline Oleria & paula & amalda, lerida \\
\hline Oleria & phenomoe & agnosia \\
\hline Oleria & quadrata & agnosia \\
\hline Oleria & quintina & quintina \\
\hline Oleria & radina & panthyale, banjana-m, \\
unknown
\end{tabular}

\section{Species Distribution}

To map species distributions we compiled a database of 5386 species-locality records. This database combines fieldwork data from the authors and records from more than 60 museums and private collections, with the most significant contributions ( $>200$ records each) from the Natural History Museum, London (BMNH), the Museo de Historia Natural, Universidad Mayor de San Marcos, Lima (MUSM), the McGuire Center, Florida Museum of Natural History, Gainesville (FLMNH), the United States National Museum, Washington D.C. (USNM), the American Museum of Natural History, New York (AMNH), and sight records (Willmott \& Hall, unpublished data). Despite ithomiines being one of the best collected Neotropical butterfly 
groups, representation is still patchy at fine scales because many regions are yet to be sampled. We therefore used species distribution modelling to better represent the distribution of species and subspecies. We used ArcGIS 9 for most geoprocessing, with the World Cylindrical Equal Area projection, and DIVA-GIS version 7.5 (http://www.diva-gis.org/) for distribution modelling. Briefly, the procedure was as follows. First, we calculated the maximum nearest neighbour distance between any two points for each species, as an approximate measure of the extent of our knowledge of the distribution of that species. For two species with disjunct ranges (Oleria aquata and Oleria victorine) we calculated this distance separately for each population. Second, for each species we created a minimum convex polygon around its distribution points buffered at the distance calculated in step 1. Third, we used the BIOCLIM model in DIVA-GIS to estimate climatically suitable areas for each species on a 2.5 min grid, using two climatic variables, Annual Mean Temperature and Annual Precipitation. We converted the resulting distributions into presence-absence rasters with a value of 0 representing absence (predicted distributions with less than $5 \%$ certainty, i.e. values of 0-50 in the DIVA-GIS output grid file), and 1 for presence (values of 50-500 in the DIVA-GIS output grid file). Fourth, we overlaid the DIVA-GIS model with the buffered minimum convex polygon, and calculated the intersection of these layers as the final predicted distribution for the species. In cases where the distribution was predicted to occur in areas without any record which were separated by a significant barrier (e.g., the Andes mountains) from areas with records, we cropped the distribution to remove those areas with no records. The resulting distribution was converted to a point shapefile (at quarter degree grid resolution) for ease of analysis. As a further step to model the distribution of subspecies, we used the Thiessen polygon (TP) tool in ArcGIS to divide the Neotropical region for each species into a series of contiguous polygons. Each polygon contains a single empirical distribution point, and everywhere within that polygon is nearer to that point than to any other point. We assumed that any modelled distribution point falling within a TP was most likely to be represented by the subspecies occurring at the source point for the TP. We thus overlaid the TP layer with our modelled point shapefiles and assigned each modelled point to a subspecies.

The resulting data were finally analysed by quarter degree grid cell. Distribution maps were overlaid to determine the species/subspecies composition and to calculate six measures of diversity listed below for each grid cell. The three measures of phylogenetic diversity were computed with the package Picante in R.

\section{Species, Mimicry and Phylogenetic Diversity}

We used several metrics to measure different aspects of ithomiine diversity in each grid cell, as outlined below:

- Species richness is the most commonly used measure of diversity, and is computed as the number of species present in each grid cell.

- Mimicry richness corresponds to the number of mimicry patterns in each grid cell. 
- Mimicry vulnerability is a relative vulnerability index based on the hypothesis that the smaller a mimicry ring, the more vulnerable it is (i.e., the more likely it is to lose species). Specifically, we define the vulnerability of mimicry ring $i$ as $1 / \mathrm{n}_{i}$, with $\mathrm{n}_{i}$ the number of species in the mimicry ring. The total vulnerability of a grid cell is the sum of vulnerabilities of each of its constituent mimicry rings $\Sigma 1 / \mathrm{n}_{i}$. The relative vulnerability of a grid cell (i.e., scaled by its species richness), is $\left(\Sigma 1 / \mathrm{n}_{i}\right) / \Sigma \mathrm{n}_{i}$. The smaller this index is, the more robust the community of the grid cell.

- Faith's Phylogenetic Diversity (PD, Faith 2002, 2008) is recognised as the most complex measure of phylogenetic diversity. It is a group measure calculated as the total branch length connecting the species present in each grid cell.

- Equal-Splits (ES, Redding et al. 2008) is a measure of evolutionary distinctiveness, and it reflects how evolutionarily isolated a species is. Unlike the other measures used, it is a species property measure obtained by dividing the evolutionary time represented by a branch equally among its daughter branches. So, species that diverge early in the tree have higher ES values because much of their evolutionary time is not shared with any other species. The ES of a grid cell is given by the sum of the ES of all species occurring in it.

- Mean PhylogeneticDiversity (MPD) is the mean phylogenetic distance between all pairs of species occurring in a grid cell. While PD and ES are expected to be influenced by species richness (see Rodrigues et al. 2005; Nipperess chapter "The Rarefaction of Phylogenetic Diversity: Formulation, Extension and Application"), MPD is totally decoupled from it. High values of MPD indicate the presence of pairs of distantly related species in the grid cell.

For all metrics, we present only results for species present in the phylogeny (i.e., we ignore the single and seven species missing from the phylogenies of Ithomia and Oleria, respectively). Including all extant species for the metrics that do not depend on the phylogeny does not affect our results and conclusions (results not shown).

\section{Results}

Ithomia Species richness (Fig. 3a, left) is low across the lowlands (Guyana shield, lower Amazon, parts of the upper Amazon, Cerrado and Atlantic Forest), and peaks along the eastern and northern Andes and in Central America. The distribution of PD and ES (Fig. 3d, e, left) is very similar to that of species richness, all peaking along the Andes. MPD is also high along the Andes, but the highest values are observed in the upper Amazon and northern Andes, including many grid cells where species richness is very low (Fig. 3f, left). Central America exhibits a low MPD despite high species richness. Mimicry richness (Fig. 3b, left) is highest in the Andes and in the southern part of Central America, and, to a lesser extent, in the upper Amazon, with little diversity in the lower Amazon, Atlantic Forest and Cerrado. Vulnerability (Fig. 3c, left) is generally lowest in areas of high species richness (Andes and Central America), but also in areas where intermediate or low 


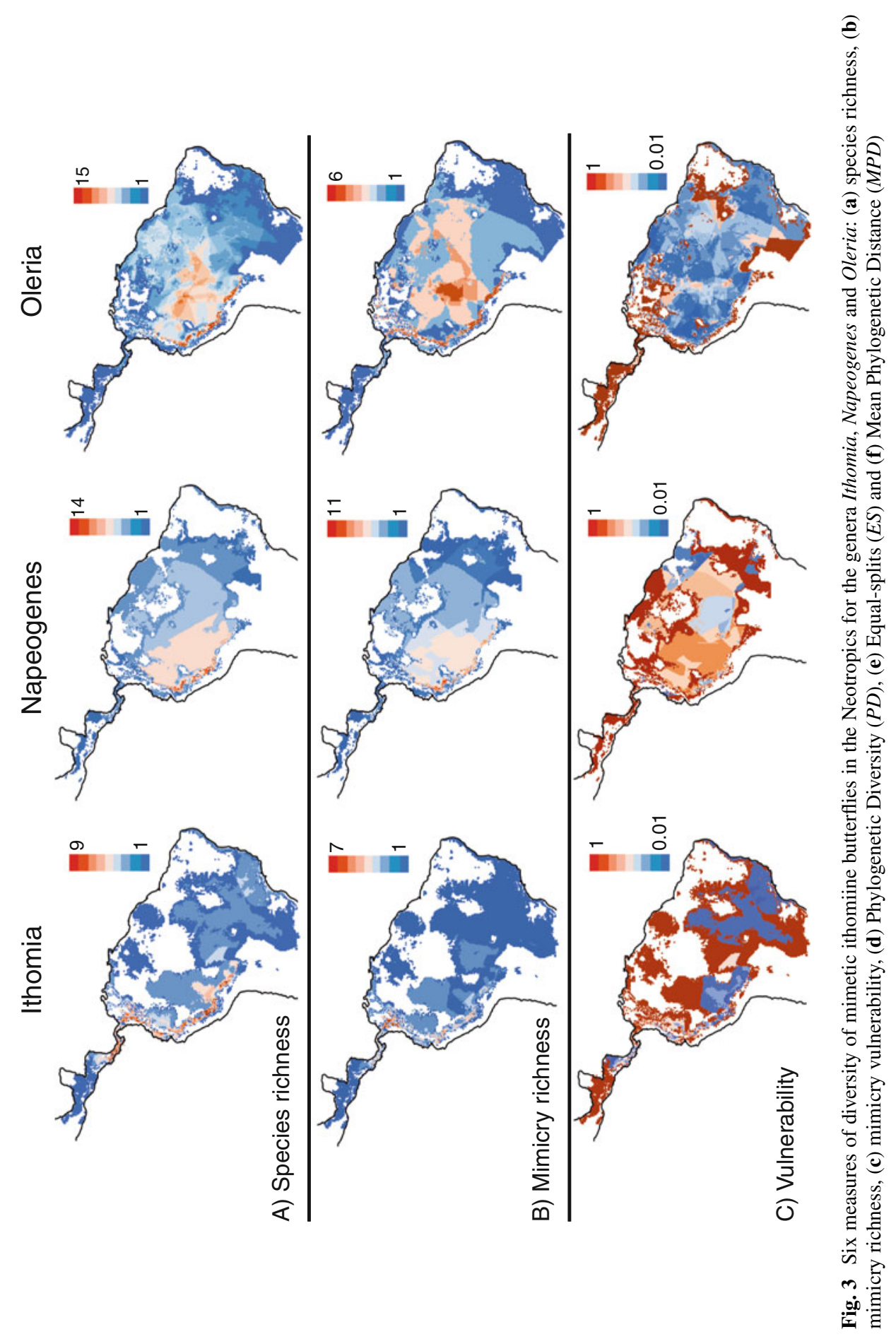




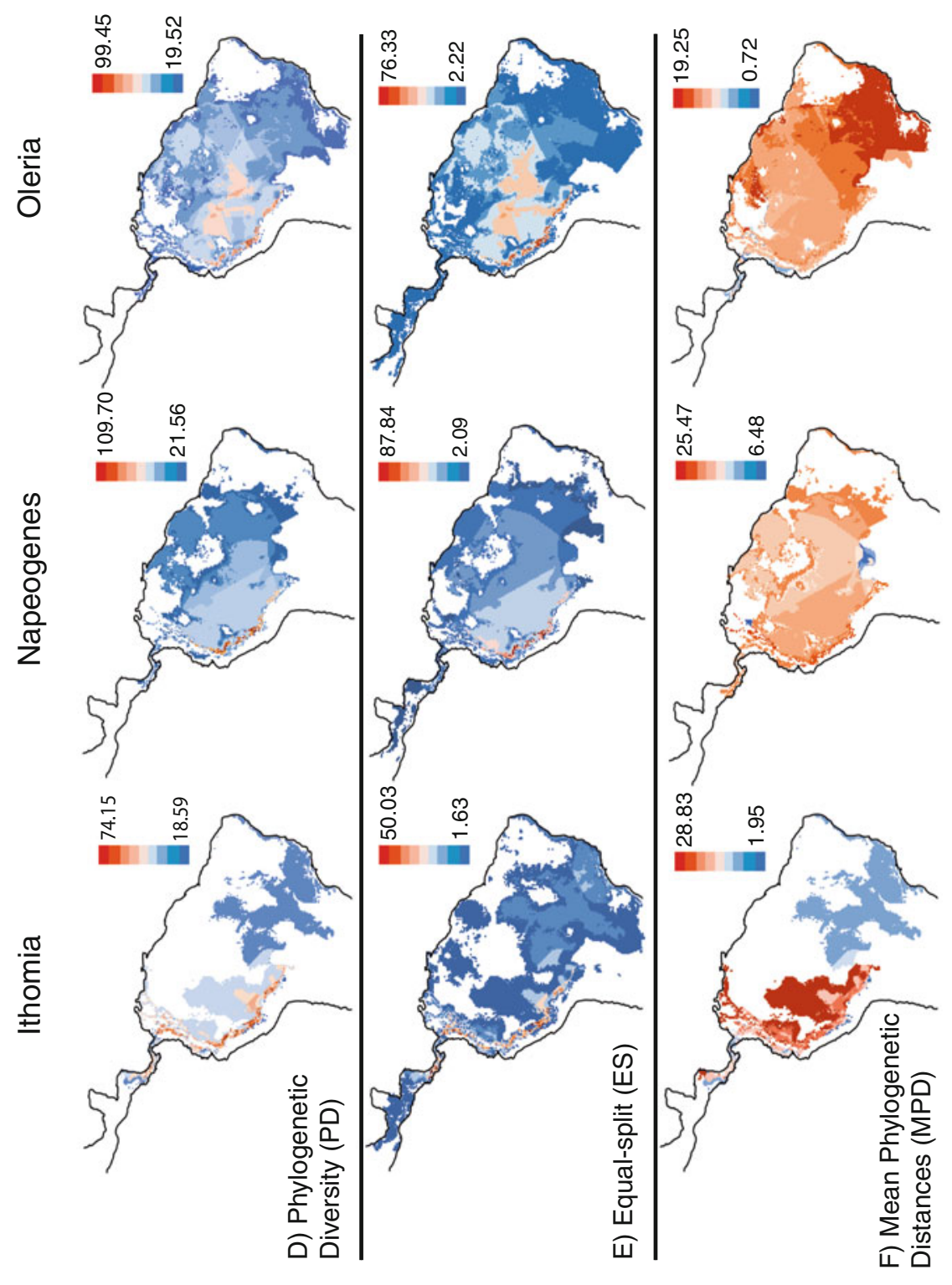

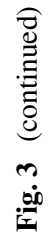


species richness is associated with low mimicry diversity (southern upper Amazon, Cerrado and Atlantic forest).

Napeogenes Species richness, mimicry richness, PD, and ES (Fig. 3a, b, d, e, middle) exhibit a nearly identical pattern. They peak along the eastern Andes, remain high in the upper Amazon, and decrease toward the east and south (Guiana shield, lower Amazon and Atlantic Forest). Northern Andes and Central America have low values for these metrics. MPD (Fig. 3f, middle) peaks all along the Andes, from south of Peru, to north Colombia, and exhibits intermediate values in the Cerrado and the edges of the lower Amazon. Vulnerability (Fig. 3c, middle) is generally high, with lowest values in the lower Amazon and in Peruvian eastern Andes. Vulnerability appears less related to species richness than for Ithomia.

Oleria Species richness, PD and ES (Fig. 3a, d, e, right) peak in the eastern Andes, followed by the upper Amazon and the western part of the lower Amazon. Central America and Atlantic Forest are low-diversity areas. Mimicry richness (Fig. 3b, right) peaks in the Andes and exhibits a second important peak in central Amazon while the Amazonian basin is mimetically rich. MPD increases from north-west (CentralAmerica) toward south-east (Atlantic Forest) (Fig. 3c, right). Mimicry vulnerability (Fig. 3c, right) is lowest in the entire Amazonian basin, Cerrado and Atlantic Forest and increases at the edges of the generic distribution and in Central America.

\section{Discussion}

Understanding global patterns of biodiversity distribution is at the core of macroecology (e.g., Gaston 2000; Gaston and Blackburn 2000; Crisp et al. 2009), and represents a basis for identifying regions that should be the focus for conservation (e.g., Myers et al. 2000). In our study we used six different measures to assess large-scale patterns of diversity for three butterfly genera in the Neotropics. These measures capture different attributes of biodiversity and their simultaneous use contributes to a better picture of how they are related. We found that the patterns of distribution of species richness, phylogenetic diversity and mimicry diversity remain relatively consistent across different ithomiine genera. However, sensitivity to extinction related to mutualistic interactions strongly varies across regions and shows incongruence across the groups studied here.

\section{Hotspots of Species Richness and Phylogenetic Diversity in the Neotropics}

For the three genera studied here, the eastern part of the Andes is one of the regions with highest species richness and phylogenetic diversity (PD and ES) while the poorest regions are the lower-Amazon, the Cerrado and the Atlantic-forest. Napeogenes and Oleria show a relatively similar secondary peak of diversity in the 
upper-Amazon. By contrast, Ithomia exhibits low diversity in the upper-Amazon but maximum species richness in Central-America. The latter pattern is due mainly to the diversification of a single clade in Central-America, which explains the relatively intermediate values of PD and ES (i.e., not maximum values). Interestingly, the Central-America diversity peak also corresponds to a mountainous region.

Within each genus, species richness, PD and ES show a very strong pattern of covariation. This is likely due to the fact that these indices are summed across all species in a grid cell and are therefore strongly influenced by species richness (see Rodrigues et al. 2005; Davies and Cadotte 2011). This may be particularly important for the three genera studied here because their phylogenetic trees are rather balanced, resulting in no major differences in phylogenetic diversity among species (see Rodrigues et al. 2005 for an analysis of PD in this respect). But, as shown in previous works, the congruence among different indices is not perfect throughout the spectrum of species richness distribution. Here, differences among measures are more obvious in areas with intermediate or intermediate to low species richness. Differences between species and phylogenetic diversity are likely to be common for relatively low species richness areas, because such areas could harbour distantly related species and/or phylogenetically distinctive species, resulting in high PD and ES values. For example, Arponen and Zupan (chapter "Representing Hotspots of Evolutionary History in Systematic Conservation Planning for European Mammals") found major differences between phylogenetic diversity and species richness for mammals in areas of low diversity in the north of Europe.

MPD captures the average relatedness of the pairs of species in each grid cell, and high values indicate the presence of pairs of distant relatives in species assemblages. As a mean value it is independent of species richness, but its variance increases with low species richness. However, it provides useful information related to the diversification history of a clade. For example, the increase of MPD for Oleria, from northwest toward southeast, is explained by phylogenetically independent colonisation of these regions.

One of the first studies investigating the usefulness of ithomiines as biogeographic indicators suggested that they could be good surrogates of total butterfly diversity in lowland Neotropical forests (Beccaloni and Gaston 1995). Our results are mostly consistent with that suggestion, since peaks in richness in the eastern Andes and upper Amazon, as identified here, have also been reported in Heliconius butterflies (Rosser et al. 2012) and the genus Adelpha (Willmott 2003).

Studies on other taxa have also found a pattern of high diversity in the upper Amazon, based on various different measures. For example, using a dataset of 50 clades (López-Osorio and Miranda-Esquivel 2010), found that species richness and evolutionary distinctiveness of several groups of vertebrates and some groups of insects and plants are high in the southern upper Amazon. But, unlike the genera studied here, they also found very high diversity in the Guianas (see also MirandaEsquivel chapter "Support in Area Prioritization Using Phylogenetic Information"). Similarly, Amori et al. 2013 noted that rodent diversity peaks in the upper Amazon, but also found diversity hotspots in the Guianas and Atlantic forest. Primates similarly show increasing diversity from east to west (Da Silva et al. 2005b), as well as birds (Haffer 1990), non-volant mammals (Costa et al. 2000) and plants (Ter Steege 
et al. 2000). Many factors are likely to contribute to the general high species richness in the western Amazon and Andean foothills. Along the eastern Andes, high turnover in abiotic conditions, habitat types, vegetation and host-plants for phytophagous insects, in addition to topological complexity, may explain a high species turnover within a grid cell, therefore increasing diversity. All these factors are also potential drivers of speciation, which also contributes to increase diversity. The diversification histories across geographical areas also account for patterns of diversity of different organisms. In the case of ithomiine butterflies, previous studies found that Napeogenes, Ithomia and Oleria likely originated in the northern Andes and subsequently diversified throughout both the Andes and the rest of the Neotropics (Elias et al. 2009; de-Silva et al. 2015; de-Silva et al. 2010). Shifts of altitudinal range and colour pattern are also correlated (Chazot et al. 2014) and are involved in speciation events (Jiggins et al. 2006; Elias et al. 2009), and may likely have increased speciation rate in montane regions. In addition, hostplant diversity has been proposed to drive diversification in phytophagous insects (Janz et al. 2006) and particularly in ithomiines (Willmott and Freitas 2006), whose Solanaceae hostplants are most diverse in the Andes and the upper Amazon, and to a lesser extent in the Atlantic Forest (Knapp 2002; PBI Solanum Project; http://www.nhm.ac.uk/ research-curation/research/projects/solanaceaesource/). Understanding the ecology and the diversification history of different groups of organisms may therefore lead to a better explanation of diversity patterns in the Neotropics and improve conservation strategies. For this reason, no single group of organism can be a good indicator of general patterns of diversity. Approaches that rely on a wide range of taxa (e.g., López-Osorio and Miranda-Esquivel 2010) are more powerful in this respect.

\section{Müllerian Mimicry: Patterns of Diversity and Community Vulnerability}

Müllerian mimicry affects both local and regional species assemblages, and mutualistic mimetic interactions have apparently led to adaptively structured assemblages (Elias et al. 2008; Chazot et al. 2014). In this study we tried to capture the importance of ecological interactions by using Müllerian mimicry as an example. We first measured mimicry pattern of richness. This measure is relatively correlated with both species richness and phylogenetic diversity and thus shows a consistent peak along the Andes across the three genera and in the upper-Amazon for Napeogenes and Oleria. Napeogenes appears to be the genus in which most mimicry patterns co-occur, and it is the most polymorphic genus studied here, with, for example, twice as many mimicry patterns as Oleria. In contrast to Oleria and Ithomia, some Napeogenes species have opaque wings with bright orange, yellow and black patterns. Interestingly, we found two main centres of similar mimicry diversity in Oleria: along the Andes and in the upper Amazon. Oleria is the most 
species-rich genus but, perhaps surprisingly, the poorest in terms of mimicry diversity. However, within genera a positive correlation between local species richness and the local number of mimicry patterns across the generic range is expected, a pattern confirmed in our analyses for all genera. This result implies that, at a local scale, preserving high species diversity should preserve mimicry diversity as well.

Mimicry ring formation is the convergence of multiple co-occurring species toward a similar aposematic colour pattern. A species benefits from the presence of locally co-mimetic species. Thus there is high interdependency between co-mimetic species, such that extinction of one species may affect its co-mimics and induce cascading extinctions. Our vulnerability metric was based on the assumption that the more species share a mimicry pattern the less species are sensitive to extinction. We found very distinct patterns across genera: (1) for Oleria, vulnerability is lowest in the upper-Amazon, Cerrado and Atlantic Forest and sharply increases at the edges of these regions and in Central America; (2) vulnerability of Napeogenes communities is high everywhere, with the lowest values in central Amazonia and east of the lower Amazon; (3) for Ithomia, the lowest vulnerability is found in the southeastern Neotropics and in Central America. Overall, these results broadly reflect the extent to which each genus numerically dominates butterfly communities in each region. Oleria are abundant members of Amazon forest communities and tend to be co-mimetic, leading to low vulnerability in these regions. Ithomia are abundant in the southwestern Amazon and Atlantic forests and in Nicaragua-Costa Rica, where they show low vulnerability, while Napeogenes, most of whose species are rare everywhere, proves also to be vulnerable everywhere.

This analysis is a preliminary exploration of the possibility of using more sophisticated measures related to the ecology of Neotropical butterflies. As such, it suffers from several problems. Our dataset includes about 100 species out of ca. 380 ithomiines species, many of which are involved in the mimicry rings considered here but ignored in our vulnerability index. Similarly, many other taxonomic groups are members of ithomiine mimicry rings, particularly Heliconiini (Nymphalidae) and several diurnal moths. Finally, mimicry rings may also involve Batesian (nonpoisonous) mimics such as some Pieridae and Nymphalidae (e.g., Beccaloni 1997a), which weakens the protection given by mimicry. Our metric may therefore misestimate (and most likely overestimate) vulnerability of some mimicry rings, particularly those found in Ithomia and Napeogenes, which include many species of other ithomiine genera. Nevertheless, despite not being optimal our vulnerability analysis draws attention to three aspects. Firstly, biotic interactions - mutualistic interactions in this case - are not homogeneously distributed across the Neotropics, and may strongly influence sensitivity to extinction of butterfly assemblages across space. Secondly, biotic interactions are not homogeneously distributed across taxa, meaning that the pattern of one clade is not necessarily similar to another one. And thirdly, because ithomiines numerically dominate many butterfly assemblages across the Neotropics, they probably condition to a certain extent the distribution of other species that interact with them in a positive or negative way. 


\section{Conclusion}

By studying large-scale diversity patterns of three butterfly genera we found a common pattern of high diversity along the eastern Andes, broadly similar to what has previously been found in other animal and plant groups. However, we also found some differences among the genera, which result from different evolutionary histories. For ithomiine butterflies, we argue that the east Andean slopes and foothills and the upper Amazon region should be the highest priority for conservation. The upper Amazon has already received attention and protected areas have been defined. Similar conservation plans should now focus on the Andean region. However, mountainous regions in Panama and Costa-Rica appear as a secondary diversity hotspot, not as rich but with highly distinct and endemic faunas that are also significant for conservation. Moreover, conservation efforts should not only focus on diversity hotspots, but also on regions where diversification is high. Diversification rates are likely to be particularly high in mountain areas, where rapid turnover of environmental conditions and complex topography are drivers of speciation.

The present study clearly shows that a continental approach can assist in identifying conservation priorities in macroregions, based on regional phylogenetic diversity and vulnerability of regional (and local) networks (in this case, using mimicry rings as a proxy), as also proposed by Arponen and Zupan (chapter "Representing Hotspots of Evolutionary History in Systematic Conservation Planning for European Mammals") for mammals in Europe. Although macroecological, regional patterns can appear imprecise and general in some cases, they are of extreme importance for identifying areas where local-scale studies should be conducted to better understand the value of the interaction networks, and their vulnerability to environmental disturbance. Furthermore, metrics which appear similar or to be surrogates of one another can be used to identify priorities among alternative sites. For example, given two sites with identical species richness, differences in phylogenetic and/or ecological indices could help to discriminate between them. In our study, mimicry diversity and vulnerability are clearly related to functional diversity. In the future, our results could be expanded with the addition of other important functional traits of these butterflies, such as body size, host plant use or flight height, helping to better understand the complex and megadiverse Neotropical communities.

Acknowledgements AVLF acknowledges support from the FAPESP (BIOTA-FAPESP 2011/50225-3), from the Brazilian Research Council-CNPq (fellowship 302585/2011-7, and "SISBIOTA-Brasil/CNPq grant 563332/2010-7), and from the collaborative grant "Dimensions US-Biota-São Paulo: Assembly and evolution of the Amazon biota and its environment: an integrated approach", US NSF, NASA, and FAPESP (2012/50260-6), and from the National Science Foundation (DEB-1256742). KRW acknowledges support from the Leverhulme Trust, the National Geographic Society, the Darwin Initiative, the National Science Foundation (DEB-0639861, DEB0103746), and the Museo Ecuatoriano de Ciencias Naturales and Ministerio del Ambiente in Quito, for support in museum and field work. We also thank the many museum curators and individuals who permitted us to examine their collections and record distributional data, especially Philip Ackery and Jim Reynolds (BMNH), Gerardo Lamas (MUSM), Robert Robbins (USNM), and Eric Quinter (AMNH). Finally, KRW thanks Jim Mallet for his support of ithomiine research 
over many years, Jason Hall for many Ecuadorian distribution records, and the multiple students, volunteers and assistants, especially Fraser Simpson, who helped in databasing specimens. ME, LdS and NC acknowledge support from CNRS (ATIP funding). NC is funded by a doctoral grant from Doctoral School ED227, Ministère de la Recherche, at the Muséum National d'Histoire Naturelle (Paris, France). Finally we acknowledge reviewers Matjaž Kuntner and Claudia Elizabeth Moreno Ortega for their comments on the manuscript.

Open Access This chapter is distributed under the terms of the Creative Commons AttributionNoncommercial 2.5 License (http://creativecommons.org/licenses/by-nc/2.5/) which permits any noncommercial use, distribution, and reproduction in any medium, provided the original author(s) and source are credited.

The images or other third party material in this chapter are included in the work's Creative Commons license, unless indicated otherwise in the credit line; if such material is not included in the work's Creative Commons license and the respective action is not permitted by statutory regulation, users will need to obtain permission from the license holder to duplicate, adapt or reproduce the material.

\section{References}

Amori G, Chiozza F, Patterson BD, Rondinini C, Schipper J, Luiselli L (2013) Species richness and distribution of Neotropical rodents, with conservation implications. Mammalia 77:1-19

Basset Y, Eastwood R, Sam L, Lohman DJ, Novotny V, Treuer T, Miller SE, Weiblen GD, Pierce NE, Bunyavejchewin S, Sakchoowong W, Kongnoo P, Osorio-Arenas MA (2013) Crosscontinental comparisons of butterfly assemblages in tropical rainforests: implications for biological monitoring. Insect Conserv Divers 6:223-233

Beccaloni GW (1997a) Ecology, natural history and behaviour of ithomiine butterflies and their mimics in Ecuador (Lepidoptera: Nymphalidae: Ithomiinae). Trop Lepidoptera 8:103-124

Beccaloni GW (1997b) Vertical stratification of ithomiine butterfly (Nymphalidae: Ithomiinae) mimicry complexes: the relationship between adult flight height and larval host-plant height. Biol J Linn Soc 62:313-341

Beccaloni GW, Gaston KJ (1995) Predicting the species richness of neotropical forest butterflies Ithomiinae (Lepidoptera, Nymphalidae) as indicators. Biol Conserv 71:77-86

Boggs CL, Watt WB, Ehrlich PR (2003) Butterflies: ecology and evolution taking flight. The University of Chicago Press, Chicago

Bonebrake TC, Ponisio LC, Boggs CL, Ehrlich PR (2010) More than just indicators: a review of tropical butterfly ecology and conservation. Biol Conserv 143:1831-1841

Brower AVZ, Willmott KR, Silva-Brandão KL, Garzón-Orduña IJ, Freitas AVL (2014) Phylogenetic relationships of ithomiine butterflies (Lepidoptera: Nymphalidae: Danainae) as implied by combined morphological and molecular data. Syst Biodivers 12(2):133-147

Brown KS (1984) Adult-obtained pyrrolizidine alkaloids defend ithomiine butterflies against a spider predator. Nature 309:707-709

Brown KS (1985) Chemical ecology of dehydropyrrolizidine alkaloids in adult Ithomiinae (Lepidoptera, Nymphalidae). Rev Bras Biol 44:435-460

Brown KS (1997) Diversity, disturbance, and sustainable use of Neotropical forests: insects as indicators for conservation monitoring. J Insect Conserv 1:25-42

Brown KS, Benson WW (1974) Adaptive polymorphism associated with multiple Müllerian mimicry in Heliconius numata (Lepid. Nymph.). Biotropica 6:205-228

Brown KS, Freitas AVL (2000) Atlantic forest butterflies: indicators for landscape conservation. Biotropica 32:934-956 
Chazot N, Willmott KR, Santacruz Endara PG, Toporov A, Hill RI, Jiggins CD, Elias M (2014) Mutualistic mimicry and filtering by altitude shape the structure of Andean butterfly Communities. Am Nat 183:26-39

Chen IC, Hill JK, Shiu HJ, Holloway JD, Benedick S, Chey VK, Barlow HS, Thomas CD (2011) Asymmetric boundary shifts of tropical montane Lepidoptera over four decades of climate warming. Glob Ecol Biogeogr 20:34-45

Costa LP, Leite YLR, da Fonseca GAB, da Fonseca MT (2000) Biogeography of South American forest mammals: endemism and diversity in the Atlantic Forest. Biotropica 32:872-881

Crisp MD, Arroyo MTK, Cook LG, Gandolfo MA, Jordan GJ, McGlone MS, Weston PH, Westoby M, Wilf P, Linder HP (2009) Phylogenetic biome conservatism on a global scale. Nature 458:754-756

Da Silva JMC, Rylands AB, Da Fonseca GAB (2005a) The fate of the Amazonian areas of endemism. Conserv Biol 19:689-694

Da Silva JMC, Rylands AB, Júnior JSS, Gascon C, da Fonseca GAB (2005b) Primate diversity patterns and their conservation in Amazonia. In: Phylogeny and conservation. University Press Cambridge, Cambridge, pp 337-364

Davies TJ, Cadotte MW (2011) Quantifying biodiversity: does it matter what we measure? In: Zachos FE, Habel JC (eds) Biodiversity hotspots. Springer, Berlin, pp 43-60

De Silva DL, Elias M, Willmott K, Mallet J, Day JJ (2015) Diversification of clearwing butterflies with the rise of the Andes. J Biogeogr (in press)

de-Silva DL, Day JJ, Elias M, Willmott K, Whinnett A, Mallet J (2010) Molecular phylogenetics of the neotropical butterfly subtribe Oleriina (Nymphalidae: Danainae: Ithomiini). Mol Phylogenet Evol 55:1032-1041

Devictor V, Mouillot D, Meynard C, Jiguet F, Thuiller W, Mouquet N (2010) Spatial mismatch and congruence between taxonomic, phylogenetic and functional diversity: the need for integrative conservation strategies in a changing world. Ecol Lett 13:1030-1040

DeVries PJ, Lande R, Murray D (1999) Associations of co-mimetic ithomiine butterflies on small spatial and temporal scales in a neotropical rainforest. Biol J Linn Soc 67:73-85

Duarte LDS, Prieto PV, Pillar VD (2012) Assessing spatial and environmental drivers of phylogenetic structure in Brazilian Araucaria forests. Ecography 35:952-960

Elias M, Gompert Z, Jiggins C, Willmott K (2008) Mutualistic interactions drive ecological niche convergence in a diverse butterfly community. Plos Biol 6:2642-2649

Elias M, Joron M, Willmott K, Silva-Brandao KL, Kaiser V, Arias CF, Pinerez LMG, Uribe S, Brower AVZ, Freitas AVL, Jiggins CD (2009) Out of the Andes: patterns of diversification in clearwing butterflies. Mol Ecol 18:1716-1729

Engler R, Randin CF, Vittoz P, Czaka T, Beniston M, Zimmermann NE, Guisan A (2009) Predicting future distributions of mountain plants under climate change: does dispersal capacity matter? Ecography 32:34-45

Faith DP (1992) Conservation evaluation and phylogenetic diversity. Biol Conserv 61:1-10

Faith DP (2002) Quantifying biodiversity: a phylogenetic perspective. Conserv Biol 16:248-252

Faith DP (2008) Threatened species and the potential loss of phylogenetic diversity: conservation scenarios based on estimated extinction probabilities and phylogenetic risk analysis. Conserv Biol 22:1461-1470

Feeley KJ, Silman MR, Bush MB, Farfan W, Cabrera KG, Malhi Y, Meir P, Revilla NS, Quisiyupanqui MNR, Saatchi S (2011) Upslope migration of Andean trees. J Biogeogr 38:783-791

Flynn DFB, Mirotchnick N, Jain M, Palmer MI, Naeem S (2011) Functional and phylogenetic diversity as predictors of biodiversity-ecosystem-function relationships. Ecology 92:1573-1581

Gaston KJ (2000) Global patterns in biodiversity. Nature 405:220-227

Gaston KJ, Blackburn TM (2000) Pattern and process in macroecology. Blackwell Science, Oxford

Gaston KJ, Hudson E (1994) Regional patterns of diversity and estimates of global insect species richness. Biodivers Conserv 3:493-500

Griscom HP, Ashton MS (2011) Restoration of dry tropical forests in Central America: a review of pattern and process. For Ecol Manage 261:1564-1579 
Haffer J (1990) Avian species richness in tropical South-America. Stud Neotropical Fauna Environ 25:157-183

Hartmann K, Andre J (2013) Should evolutionary history guide conservation? Biodivers Conserv 22:449-458

Hartmann K, Steel MA (2007) Phylogenetic diversity: from combinatorics to ecology. In: Gascuel O, Steel MA (eds) Reconstructing evolution: new mathematical and computational advances. Oxford University Press, New York, pp 171-196

Hawkins BA, Diniz-Filho JAF, Jaramillo CA, Soeller SA (2007) Climate, niche conservatism, and the global bird diversity gradient. Am Nat 170:S16-S27

Hill RI (2010) Habitat segregation among mimetic ithomiine butterflies (Nymphalidae). Evol Ecol 24:273-285

Howard PC, Viskanic P, Davenport TRB, Kigenyi FW, Baltzer M, Dickinson CJ, Lwanga JS, Matthews RA, Balmford A (1998) Complementarity and the use of indicator groups for reserve selection in Uganda. Nature 394:472-475

Janz N, Nylin S, Wahlberg N (2006) Diversity begets diversity: host expansions and the diversification of plant-feeding insects. BMC Evol Biol 6:4

Jiggins CD, Mallarino R, Willmott KR, Bermingham E (2006) The phylogenetic pattern of speciation and wing pattern change in neotropical Ithomia butterflies (Lepidoptera: Nymphalidae). Evolution 60:1454-1466

Knapp S (2002) Assessing patterns of plant endemism in neotropical uplands. Bot Rev 68:22-37

Lamas G (2004) Checklist: Part 4A. Hesperioidea - Papilionoidea. In: Atlas of neotropical Lepidoptera. Scientific Publisher, Gainesville

Lamoreux JF, Morrison JC, Ricketts TH, Olson DM, Dinerstein E, McKnight MW, Shugart HH (2006) Global tests of biodiversity concordance and the importance of endemism. Nature 440:212-214

Loiselle BA, Graham CH, Goerck JM, Ribeiro MC (2010) Assessing the impact of deforestation and climate change on the range size and environmental niche of bird species in the Atlantic forests, Brazil. J Biogeogr 37:1288-1301

López-Osorio F, Miranda-Esquivel DR (2010) A phylogenetic approach to conserving Amazonian biodiversity. Conserv Biol 24:1359-1366

Mace GM, Gittleman JL, Purvis A (2003) Preserving the tree of life. Science 300:1707-1709

Maclaurin J, Sterelny K (2008) What is biodiversity. The University of Chicago Press, Chicago

Mallarino R, Bermingham E, Willmott KR, Whinnett A, Jiggins CD (2005) Molecular systematics of the butterfly genus Ithomia (Lepidoptera: Ithomiinae): a composite phylogenetic hypothesis based on seven genes. Mol Phylogenet Evol 34:625-644

Mallet J (1999) Causes and consequences of a lack of coevolution in Mullerian mimicry. Evol Ecol 13:777-806

Mooers AO, Heard SB, Chrostowski E (2005) Evolutionary heritage as a metric for conservation. In: Purvis A, Gittleman JL, Brooks T (eds) Phylogeny and conservation, Cambridge University Press, pp 120-138

Müller F (1879) Ituna and Thyridia; a remarkable case of mimicry in butterflies. Trans Entomol Soc Lond, $\mathrm{xx}$-xxix

Myers N, Mittermeier RA, Mittermeier CG, da Fonseca GAB, Kent J (2000) Biodiversity hotspots for conservation priorities. Nature 403:853-858

New TR (1993) Angels on a pin - dimensions of the crisis in invertebrate conservation. Am Zool 33:623-630

Purvis A, Agapow PM, Gittleman JL, Mace GM (2000) Nonrandom extinction and the loss of evolutionary history. Science 288:328-330

Redding DW, Hartmann K, Mirnoto A, Bokal D, Devos M, Mooers AO (2008) Evolutionarily distinctive species often capture more phylogenetic diversity than expected. J Theor Biol 251:606-615

Ribeiro MC, Metzger JP, Martensen AC, Ponzoni FJ, Hirota MM (2009) The Brazilian Atlantic forest: how much is left, and how is the remaining forest distributed? Implications for conservation. Biol Conserv 142:1141-1153 
Rodrigues ASL, Brooks TM, Gaston KJ (2005) Integrating phylogenetic diversity in the selection of priority areas for conservation: does it make a difference? In: Purvis A, Gittleman JL, Brooks T (eds) Phylogeny and conservation, Cambridge University Press, pp 101-119

Rosser N, Phillimore AB, Huertas B, Willmott KR, Mallet J (2012) Testing historical explanations for gradients in species richness in heliconiine butterflies of tropical America. Biol J Linn Soc 105:479-497

Safi K, Cianciaruso MV, Loyola RD, Brito D, Armour-Marshall K, Diniz JAF (2011) Understanding global patterns of mammalian functional and phylogenetic diversity. Phil Trans R Soc B-Biol Sci 366:2536-2544

Samways MJ (1994) Insect conservation biology. Chapman \& Hall, London

Schweiger O, Klotz S, Durka W, Kuhn I (2008) A comparative test of phylogenetic diversity indices. Oecologia 157:485-495

Sheldon KS, Yang S, Tewksbury JJ (2011) Climate change and community disassembly: impacts of warming on tropical and temperate montane community structure. Ecol Lett 14:1191-1200

SOS Mata Atlântica, INPE, ISA, eds (1998) Atlas da Evolução dos Remanescentes Florestais e Ecosistemas Associados do Domínio da Mata Atlântica no Período 1990-1995, Fundação SOS Mata Atlântica, Instituto National de Pesquisas Espaciais e Instituto Socioambiental, São Paulo

Sparrow HR, Sisk TD, Ehrlich PR, Murphy DD (1994) Techniques and guidelines for monitoring neotropical butterflies. Conserv Biol 8:800-809

Ter Steege H, Sabatier D, Castellanos H, Van Andel T, Duivenvoorden J, De Oliveira AA, Ek R, Lilwah R, Maas P, Mori S (2000) An analysis of the floristic composition and diversity of Amazonian forests including those of the Guiana Shield. J Trop Ecol 16:801-828

Vane-Wright RI, Humphries CJ, Williams PH (1991) What to protect - systematics and the agony of choice. Biol Conserv 55:235-254

Warren MS, Hill JK, Thomas JA, Asher J, Fox R, Huntley B, Roy DB, Telfer MG, Jeffcoate S, Harding P, Jeffcoate G, Willis SG, Greatorex-Davies JN, Moss D, Thomas CD (2001) Rapid responses of British butterflies to opposing forces of climate and habitat change. Nature 414:65-69

Williams P, Gibbons D, Margules C, Rebelo A, Humphries C, Pressey R (1996) A comparison of richness hotspots, rarity hotspots, and complementary areas for conserving diversity of British birds. Conserv Biol 10:155-174

Willmott KR (2003) Cladistic analysis of the Neotropical butterfly genus Adelpha (Lepidoptera: Nymphalidae), with comments on the subtribal classification of Limenitidini. Syst Entomol 28:279-322

Willmott KR, Freitas AVL (2006) Higher-level phylogeny of the Ithomiinae (Lepidoptera: Nymphalidae): classification, patterns of larval hostplant colonization and diversification. Cladistics 22:297-368

Willmott KR, Lamas G (2007) A revision of Pachacutia, a new genus of rare Andean ithomiine butterflies (Nymphalidae: Ithomiinae), with the description of two new species. Ann Entomol Soc Am 100:449-469

Willmott KR, Mallet J (2004) Correlations between adult mimicry and larval host plants in ithomfine butterflies. Proc R Soc B-Biol Sci 271:S266-S269

Yessoufou K, Daru BH, Davies TJ (2012) Phylogenetic patterns of extinction risk in the eastern arc ecosystems, an African biodiversity hotspot. PLoS One 7:e47082 